\title{
Vicente Machado da Silva Lima: entre amor e ódio, notas iniciais sobre a biografia, trajetória política e transferências de capitais
}

\author{
Mônica Helena Harrich Silva Goulart 1
}

RESUMO: O presente texto tem como objetivo apresentar, através da perspectiva sociológica bourdieusiana, aspectos iniciais acerca da trajetória política, da biografia e dos capitais políticos e econômicos decorrentes das relações de parentesco de Vicente Machado da Silva Lima. Vicente Machado foi a figura política de maior destaque durante toda a República Velha no Paraná. Apesar de ter emplacado muitos inimigos, alcançou a maioria de seus propósitos ocupando vários cargos e comandando o Partido Republicano Federal - PRF. Um dos nomes mais citados em toda imprensa local, que se dividia claramente em suas posições. Parte dela o exaltava como liderança a ser seguida, ao mesmo tempo em que seus oponentes o acusavam severamente de ser um político autoritário e contraditório, não se valendo de modelo ético. Diante das divergências impostas pela Revolução Federalista, Vicente Machado construiu seu legado. $O$ trabalho apresentado se constitui no ponto de partida de projeto de pesquisa mais amplo, cujo propósito é levantar sociologicamente a vida de Vicente Machado da Silva Lima. Sem dúvida alguma, um dos mais significativos atores políticos da história do Paraná republicano. Sua morte, em março de 1907, reconfigurou o poder político e o sistema partidário da época. Para tal pesquisa, serão utilizadas obras biográficas sobre os governantes paranaenses e textos que apontem a dinâmica do jogo político. Serão consultados jornais, por meio da hemeroteca e, posteriormente, documentos diversos como os anais da Assembleia Legislativa do Paraná, as mensagens políticas dos governadores do estado, os discursos proferidos por Vicente Machado no Senado e na ALEP, além de telegramas e documentos oficiais.

Palavras-chave: Vicente Machado. Política Paranaense. República Velha.

\section{Vicente Machado da Silva Lima: between love and hate, initial notes on the biography, political trajectory and capita transfers}

\begin{abstract}
The present text aims to present, through the Bourdieusian sociological perspective, initial aspects about the political trajectory, biography and political and economic capitals resulting from the relations of kinship of Vicente Machado da Silva Lima. Vicente Machado was the most prominent political figure throughout the Old Republic in Paraná. Despite having staged many enemies, he achieved most of his purposes by occupying various positions and commanding the Federal Republican Party (PRF). One of the most cited names in all local press, which was clearly divided into their positions. Part of it exalted him as a leader to be followed, while his opponents accused him severely of being an authoritarian and contradictory politician, not using an ethical model. Faced with the divergences imposed by the Federalist Revolution, Vicente Machado built his legacy. The work presented constitutes the starting point of a broader research project, whose purpose is to raise sociologically the life of Vicente Machado da Silva Lima. Undoubtedly, one of the most significant political actors in the history of the republican Paraná. His death, in March 1907, reconfigured the political power and party system of the time. For such research, will be used biographical works on the Paranaan rulers and texts that point to the dynamics of the political game. Newspapers will be consulted, through the newspaper library and later, various documents such as the annals of the Legislative Assembly of Paraná, the political messages of state governors, the speeches given by Vicente Machado in the Senate and ALEP, as well as official telegrams and documents.
\end{abstract}

Keywords: Vicente Machado. Political Paranaense. Old Republic

- Enviado em 01/05/2017

- Aprovado em 17/05/2017

1 Doutora em Sociologia pela UFPR. Professora Adjunta na área de Sociologia Política, na UTFPR. Uma versão preliminar desse texto foi apresentada no VIII Seminário Nacional de Sociologia e Política realizado de 17 a 19 de maio de 2017 na UFPR. E-mail: mharrich@uol.com.br 


\section{INTRODUÇÃO}

Antes de iniciarmos os apontamentos preliminares acerca da biografia e trajetória política de Vicente Machado, vale mencionar que os anos que marcam a República Velha no Paraná delimitados no campo político, no sistema partidário, no coronelismo paranaense, nas fraudes eleitorais, nas relações de poder, na dinâmica entre legislativo e executivo, e na própria organização social, não podem ser pensados sem a relação, direta ou indireta, da figura vicentista.

Vicente Machado viveu somente 46 anos e poucos meses, mas interferiu sobremaneira em toda história política do estado do Paraná. Dono de comentários positivos e de enormes críticas, seu nome é também chave para entendimento da conjuntura política do Paraná de 1889 até 1930. Pouco se sabe, muito se apontou e quase nada se tem produzido sobre os atores políticos paranaenses, principalmente sobre Vicente Machado.

Isto posto, não queremos balizar o Paraná da República Velha somente pela atuação de Vicente Machado, tão pouco o reduzir pela sua época e contexto. Nem mesmo pretendemos ter como definido a ideia acabada de que se pode apreender tudo sobre o personagem e sobre seu tempo. Daí a perspectiva fundamental da construção de uma biografia sociológica ${ }^{2}$, conforme aponta Bourdieu, através das palavras de Montagner (2007):

(...) uma trajetória é a objetivação das relações entre os agentes e as forças presentes no campo. Essa objetivação resulta em uma trajetória, que diferentemente das biografias comuns, descreve a série de posições sucessivamente ocupadas pelo mesmo escritor em estados sucessivos do campo literário. (...) a biografia à lá Bourdieu independe do indivíduo, está ligada ao conceito de agente operando em um campo de forças, muitas vezes sem atinar para o sentido real de sua ação, em um conjunto mais vasto de caminhos possíveis à sua geração. (MONTAGNER, 2007, p. 254,255)

Em poucas palavras, percorrer uma trajetória, portanto, nada mais é do que buscar o equilíbrio entre a biografia, a vida de um agente político e o seu contexto, suas inserções nos diversos campos sociais. Diante de toda complexidade desta tarefa, nosso objetivo é demarcar esse equilíbrio pensando e compreendendo a atuação de Vicente Machado em meio ao fim do Império e República Velha, no Paraná e no Brasil.

\footnotetext{
2 Como exemplo de biografia sociológica temos o excelente trabalho de Ana C. Vanali (2017), sobre a trajetória do republicano histórico Manoel Correia Defreitas.
} 


\section{TRAÇOS BIOGRÁFICOS INICIAIS E CAPITAIS ALCANÇADOS}

Vicente Machado da Silva Lima nasceu em Castro, em 9 de agosto de 1860. Filho do Dr. José Machado da Silva Lima, nascido em 1822, e de sua segunda esposa Anna Guilhermina Laynes Pinheiro Lima, ambos de Paranaguá. (NíCOLAS, 1984).

A genealogia de Vicente Machado está presente no levantamento de Francisco Negrão, formalizado na Genealogia Paranaense (1926), tanto como nos escritos de Luiz Gonzaga da Silva Leme, na Genealogia Paulistana (1905). Segundo Oliveira (2001, p. 298), dos oito ${ }^{3}$ governadores eleitos durante a República Velha, sete pertenciam aos títulos familiares históricos e hegemônicos da formação inicial do estado.

Vicente Machado é descente dos primeiros povoadores das terras paranaenses, ligando-o ao Título Carrasco dos Reis - designação feita ao primeiro povoador que recebeu terras de sesmarias do então Capitão-mor Governador do Rio de Janeiro, Salvador Correia de Sá e Benevides. Baltazar Carrasco dos Reis, casado com Izabel Antunes da Silva, mudou-se para Curitiba ainda na metade do século XVII. O próprio nome Carrascos, que tem origem espanhola e, segundo Francisco Negrão e Luiz Gonzaga da Silva Leme, ao mesmo tempo, se remete ao local onde, ainda que de moradia provisória, o pai de Baltazar4, Miguel Garcia, morou. (NEGRÃO, 1926; OLIVEIRA, 2001).

Trilhando a presente linhagem, tem-se na ascendência de Vicente Machado os seguintes nomes: Baltazar Carrasco dos Reis, Gaspar Carrasco dos Reis (o segundo filho de Baltazar), Baltazar Velloso e Silva, Cap. Agostinho da Silva Valle, Maria Camila de Lima casada com Cap. João Machado da Silva Lima (cuja genealogia, também muito importante, está presente em Curitiba desde o século XVII) e o cap. José Machado da Silva Lima - pai de Vicente Machado. Pode-se dizer que o fato de ser descendente de Baltazar Carrasco dos Reis já o torna portador de relevante prestígio regional, assim como os demais descendentes.

\footnotetext{
3 Governadores com títulos: Generoso Marques dos Santos (1891), Vicente Machado (1893-1894, 1904-1907), José Pereira dos Santos Andrade (1896-1900), João Cândido Ferreira (1904, 1905, 1906, 1907 - substituindo V.M. e, depois, eleito e impedido de assumir o cargo), Carlos Cavalcanti de Albuquerque (1912-1913), Afonso Alves de Camargo (1916-19120, 1928-1930) e Caetano Munhoz da Rocha (1920-1924-1924-1928). Além do governador Francisco Xavier da Silva (1892-1896, 1900-1904, 1908-1912), o único que não possui título familiar histórico.

${ }^{4}$ Dois de seus oito filhos, André Fernandes dos Reis e Gaspar Carrasco dos Reis assinaram, em 4 de novembro de 1668, o termo de levantamento do Pelourinho da Vila de Curitiba. (NEGRÃO, 1926, p. 157).
} 
Do primeiro casamento do cap. José Machado da Silva Lima (nascido em 1822) com Maria Clara Pinheiro Lima, teve os seguintes filhos: Dr. José Machado Pinheiro Lima5 ${ }^{5}$ Maria Eugênia de Lima $^{6}$ e Cel. Benigno Augusto Pinheiro Lima7 . Do segundo matrimônio, realizado com sua cunhada, Anna Guilhermina Pinheiro Lima, teve: Vicente Machado da Silva Lima, José Eugênio Pinheiro Lima $^{8}$, Octávio Elpídio Machado Lima ${ }^{9}$, Maria Camila de Lima Menezes ${ }^{10}$ e Heitor, que faleceu solteiro. (NEGRÃO, 1926).

O cap. José Machado da Silva Lima possuía importantes capitais ${ }^{11}$, os quais foram favoráveis à Vicente Machado em sua trajetória política. Em destaque, no ano de 1859, a 25 de fevereiro, assinou a Ata de Instalação da Biblioteca Pública da Província do Paraná, como uma espécie de secretário descreveu a referida sessão de instalação e apresentou as primeiras doações materiais (recursos financeiros, livros e outros bens do tipo cadeiras, mesas...), bem como listou os demais responsáveis pelo órgão recém-criado. (DOCUMENTOS, 1972).

Exerceu o cargo de secretário de polícia da Província paranaense, conforme consta no jornal Dezenove de Dezembro, de 10 de outubro de 1857, foi nomeado através de Decreto do Imperador, em 22 de setembro de 1856, com o salário idêntico ao de chefe de polícia que, na época, era o dr. Luiz Francisco da Camara Leal. (PARTE OFICIAL, 1857). Em 28 de fevereiro de 1860, José Machado

\footnotetext{
${ }^{5}$ Bacharel em Direito, Ministro do Tribunal de Justiça de São Paulo e deputado provincial. Casado com Máxima Moreira Lima, filha de Antonio Moreira Lima, que também foi o primeiro sogro de Vicente Machado. (NEGRÃO, 1926; LEME, 1905).

${ }^{6}$ Faleceu solteira, em São Paulo. (NEGRÃO, 1926).

${ }^{7}$ Nasceu em Paranaguá, no dia 12 de abril de 1850. Faleceu em Antonina, a 8 de outubro de 1920, local onde foi chefe político de significativa importância, jornalista, coletor de rendas do estado e também "advogado" sem diploma. Deputado estadual na ALEP no período de 1906-1907, eleito pelo Partido Republicano Federal. (NEGRÃO, 1926; GOULART, 2014).
}

${ }^{8}$ Foi casado com Ventúria Lima, em Itatiba, São Paulo. (NEGRÃO, 1926). Local onde faleceu seu pai.

${ }^{9}$ Contador dos Correios do Paraná e Promotor Público em Jacarezinho. (NEGRÃO, 1926).

10 Primeira esposa do Ten. Cel. do Exército Adalberto Gonçalves de Menezes, comandante do 3o Batalhão de Caçadores de Joinville. (NEGRÃO, 1926).

${ }^{11} \mathrm{Na}$ perspectiva bourdieusiana, os capitais são entendidos como capitais simbólicos, são créditos simbólicos de reconhecimento que conferem atributos, recursos, importância, poder e prestígio para aqueles que os detém. Em certas relações sociais podem promover mudanças nas posições dos agentes. (GOULART, 2014). Existem vários tipos ou espécies de capitais como: político, econômico, social, intelectual. MONTEIRO (2017) chama a atenção para o capital político-familiar, pois está relacionado ao poder que certas relações de parentesco e sobrenomes podem acrescentar e conferir aos indivíduos no campo político. 
da Silva Lima pediu demissão de seu cargo de secretário de polícia da Província. (PARTE OFICIAL,1860).

Logo em seguida, 1861, foi nomeado promotor público da Comarca de Castro. (NOTÍCIAS, 1861). Ato de nomeação revogado, pois foi demitido do cargo apenas dois meses depois, conforme notícia do Correio Oficial. (NOTÍCIAS, 1861). Também exerceu a atividade de presidente da Associação Patriótica Defensora da Nação em 1863, época em que a residência da família passou a ser em Ponta Grossa. (EXTRATO, 1863). Nesse local exercia com muita intensidade a atividade de advogado, ainda que sem diploma em Direito. No mesmo ano, concorreu a uma cadeira na Assembleia Provincial, porém não obteve votos suficientes para compor o quadro legislativo. (CANDIDATOS, 1863). Voltou a candidatar-se em 1873, mas novamente não conseguiu se eleger. (EDITAIS, 1873). Contudo, para vereador em Antonina, no mencionado pleito, conquistou o primeiro lugar nas eleições, recebendo 216 votos, tornando-o presidente da câmara municipal. (ANTONINA, 1873).

O cap. José Machado da Silva Lima faleceu no dia 15 de junho de 1884, em Itatiba, São Paulo. (ANÚNCIOS, 1884).

Diferente se sua condição autodidata, cuidou para que ao menos parte seus filhos se tornasse bacharéis.

Vicente Machado da Silva Lima realizou seus estudos iniciais em Castro.

Aos 16 anos entrou para a Faculdade de Direito de São Paulo ${ }^{12}$ e, aos 21 anos de idade, concluiu o curso de Bacharel em Direito. Contemporâneo de Júlio de Castilho, Silva Jardim, Julio de Mesquita e Assis Brasil. No ano de sua formatura, 1881, foi nomeado promotor público em Curitiba, cargo relevante para um estudante recém-formado. Nesse período, intitulava-se como abolicionista radical e também republicano, ainda durante o Império. Segundo Negrão (1926), nas palavras de Domingos Nascimento, Vicente Machado era “(...) um boêmio de ousadia e de talento. "Além de "(...) abolicionista entusiasta e de democrata exaltado"; já para Sebastião Paraná, Vicente Machado “(...) se distinguiu pela sua inteligência máscula” e também como um “(...) orador eloquente". (NEGRÃO, 1926, p. 268).

Em 1882 foi nomeado secretário do governador da Província do Paraná, o conselheiro Carlos de Carvalho. Lecionou filosofia no Instituto Paranaense. Em 1883 tornou-se juiz municipal

\footnotetext{
12 Jornal O Dia, em 27 de março de 1907.
} 
em Ponta Grossa, sendo nomeado juiz de órfãos no município. Pouco tempo depois de instalado na cidade, montou um escritório de advocacia em Ponta Grossa para dar início à sua trajetória política. Foi também chefe de polícia no governo provisório de Francisco José Cardoso Junior e chefe da superintendência de ensino no ano de 1884, paralelamente, colaborava com artigos para os jornais Dezenove de Dezembro e A Província do Paraná.

Vicente Machado casou-se duas vezes, ambas filhas de indivíduos importantes da política e da economia paranaense e de São Paulo. Ou seja, por meio do casamento agregou prestígio e alavancou seu capital político e também econômico. Vários autores (OLIVEIRA, 2012; MONTEIRO, 2016; CANÊDO, 1994; NIESS, 2012; ALVES, 2015; BOURDIEU, 2008) conferem significativa importância para o casamento como forma de agregar capital político decorrente da família, principalmente do sogro. A influência recebida de cunhados, tios e primos dos novos laços de parentescos também pode ser significativa.

Sua primeira esposa foi Maria Antonia Moreira Lima, falecida em 1 으 de março de 1896, filha do capitão da Guarda Nacional Antonio Moreira Lima e de Constança Alves. (TESTAMENTO, 1907). Vicente Machado foi genro, portanto, de um dos fazendeiros de café e escravocratas mais importantes da região de Itatiba, estado de São Paulo, e membro do Partido Conservador.

Neste matrimônio o casal teve quatro filhos: Dr. Caio Gracho Machado Lima ${ }^{13}$, casado com Ercília Coelho; Dr. Antonio Jorge Machado da Silva Lima ${ }^{14}$, casado com Zayra de Abreu; Dr. Vicente Machado Filho ${ }^{15}$, casado com Ondila Cordeiro Machado; João Antonio Machado Lima ${ }^{16}$; e Valentina, falecida.

13 Formado pela Escola de Ciências Políticas em Paris, França. Nasceu no dia 10 de maio de 1885. Teve várias atividades públicas, entre elas: diretor de estatística do arquivo público do Paraná, juiz do Tribunal de Contas do Paraná, delegado da inspetoria geral de bancos, membro do Conselho Administrativo do Paraná; realizou viagens para a Europa com objetivo de propagandear a erva-mate. Jornalista no Rio de Janeiro e no Paraná. Em termos de cargos político eletivos, foi deputado estadual na ALEP 1908-1909, pelo Partido Republicano Federal, 1930-1931 pelo Partido Republicano Paranaense e em 1935, 1936-1937 pelo Partido Social Democrático. Faleceu no dia 2 de fevereiro de 1954. (GOULART, 2014; 2016).

${ }^{14}$ Antonio Jorge nasceu em Ponta Grossa, a 26 de outubro de 1886. Bacharel em Direito, promotor público em Palmeira e Antonina, procurador fiscal da Fazenda Nacional, jornalista, foi um dos líderes civis na Revolução de 1930 no Paraná, além de membro do Conselho Consultivo do Paraná. Deputado constituinte pelo Paraná em 1934, eleito senador pelo Paraná entre 1935-1937. No final dos anos 1930 assumiu cargo no Tribunal de Contas da União, no início como procurador e, posteriormente, como auditor. Faleceu em 1960. (LIMA, 2017).

${ }^{15}$ Vicente Machado Filho, advogado. (NEGRÃO, 1926).

${ }^{16}$ Fiscal dos impostos de consumo, no interior do Paraná. (NEGRÃO, 1926). 
Seu segundo casamento ocorreu com Helena de Loyola Machado ${ }^{17}$, a 6 de fevereiro de 1897, filha do coronel Joaquim Antonio de Loyola e de Guilhermina dos Santos Loyola. Novamente as relações de parentesco conferem a Vicente Machado poder e prestígio, só que, desta vez, agregou capital a partir da economia ervateira, principal fonte de renda de seu sogro, o cel. Joaquim Antonio de Loyola ${ }^{18}$. Membro de família tradicional do Paraná, foi importante liderança política de Antonina, chefe da coletoria estadual de rendas, em Curitiba (entre os anos de 19041911), e abastado industrial de erva-mate desde a época do império. Vinculado ao Partido Republicano Federal (vicentista), exerceu o cargo de deputado estadual na Assembleia Legislativa do Paraná - ALEP - em várias legislaturas: 1894-1895, 1896-1897, 1898-1899 e 1900-1901.

De Helena de Loyola Machado, Vicente Machado teve os seguintes filhos: Laura Loyola Machado Lima; Vicente, falecido; Sarah Machado Cavalcanti, casada com Tenente Leo Cavalcanti ${ }^{19}$; e, Gastão de Loyola Machado Lima. (NEGRÃO, 1926; O TESTAMENTO, 1907).

Em relação aos cargos políticos, Vicente Machado ingressou ainda nos tempos monárquicos quando, em 1886, se candidatou pela primeira vez à Assembleia Legislativa Provincial, vinculado ao Partido Liberal, chefiado por Jesuíno Marcondes. Permaneceu neste partido até 1888, quando se lançou como republicano. (CARNEIRO; VARGAS, 1987).

\footnotetext{
${ }^{17}$ Em 1912 casou-se com Bento José Lamenha Lins. Desse matrimônio, Helena de Loyola teve dois filhos: Helena e Adolpho. (NEGRÃO, 1926). Bento José presidiu o Paraná (quando Generoso Marques foi deposto) por meio da Junta Governativa, em 1891. Foi deputado federal pelo Paraná por cinco legislaturas, nos períodos de 1895-1905 (pelo Partido Republicano Federal) e 1909-1914 (pelo Partido Republicano Paranaense), além de secretário de governo nos exercícios de Francisco Xavier da Silva e de Vicente Machado. Também possuía capitais políticos e sociais importantes, pois era filho de Adolpho Lamenha Lins (presidente provincial entre 1875-1877) e de Maria Leonor Correia de Sá Benevides (de tradicional família). Faleceu em 1922. (GOULART, 2015)

18 Vários membros da família Loyola ocuparem cargos na ALEP como deputados estaduais e também nas secretarias de governo, durante a República Velha. (GOULART, 2014; 2015).

19 Filho do engenheiro militar e ex-governador do Paraná Carlos Cavalcanti (1912-1916) e de sua esposa Francisca Munhoz Cavalcanti. Também vinculado inicialmente ao grupo político de Vicente Machado, o Partido Republicano Federal. Deputado estadual nos biênios de: 1891, 1897-1898, 1899, 1900-1901, 1902-1903. (GOULART, 2014).
} 


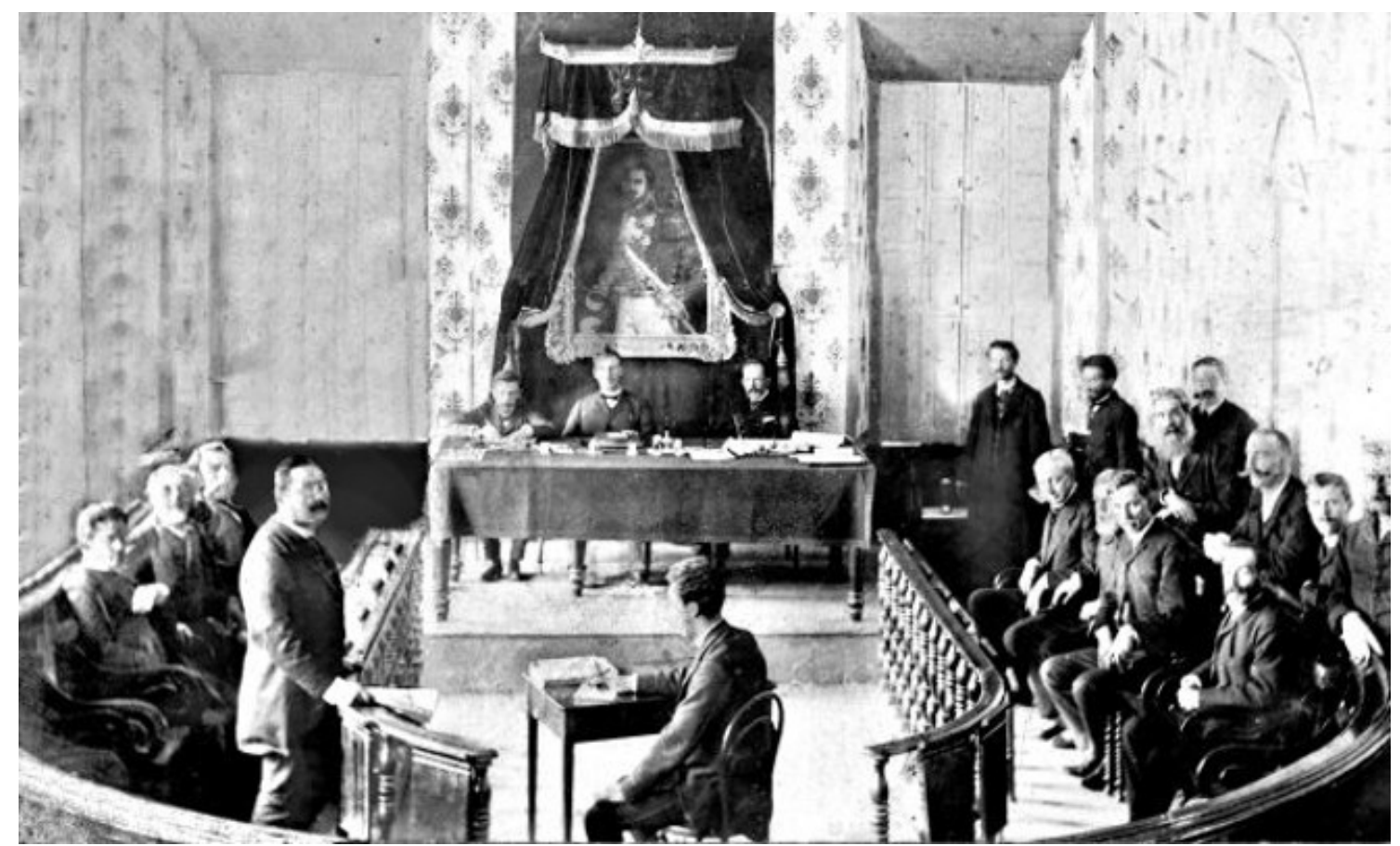

Fonte: Gazeta do Povo, acervo de Cid Destefani. Assembleia Legislativa Provincial, sessão legislativa de 1889.

Segundo Carneiro e Vargas (1987), em maio de 1889, Vicente Machado filiou-se ao Partido Conservador, vinculado aos ervateiros, porque este se apresentava como reduto dos republicanos históricos do Paraná, e porque o grupo que formava o republicanismo não teve sucesso eleitoral no Império, já que não se estruturou efetivamente no Paraná um Partido Republicano ${ }^{20}$ antes da Proclamação da República, disputando eleições e angariando cadeiras, tanto no parlamento estadual quanto nas esferas municipais.

Nesse sentido, deve-se considerar que entre as primeiras medidas após a proclamação da República, a exigência de que as autoridades políticas da época se organizassem em torno de um único Partido Republicano foi decisiva. Mas, tal agremiação não se montou rapidamente, tão pouco os integrantes dos antigos partidos políticos (liberal e conservador) conseguiram se

\footnotetext{
20 Embora David Carneiro e Túlio Vargas mencionem a existência de uma agremiação intitulada Partido Republicano no Paraná ainda nos tempos do Império, até o presente momento as pesquisas revelam a organização dos preclaros republicanos somente em torno de Clubes Republicanos. O jornal A República se apresentava no Império como órgão do Clube Republicano e, somente nos últimos meses de 1889, como órgão do Partido Republicano. Nesse aspecto, há que se insistir na necessidade de uma pesquisa detalhada a respeito dos partidos políticos no Paraná durante os últimos anos do Império e durante toda a Primeira República. Contudo, até o presente momento, tal organização, fundada em termos republicanos e federalistas, somente teve visibilidade na conjuntura após o 15 de novembro de 1889, mesmo assim, a organização partidária não ocorreu de forma imediata e tão menos sem a presença de tensões políticas. (GOULART, 2014).
} 
organizar harmonicamente numa sigla específica; base da lógica política do monopartidarismo estadual, ratificado de 1889 a 1930. (GOULART, 2014). O fato é que os que se diziam republicanos, os antigos liberais e conservadores tiveram dificuldades em conciliar seus diferentes interesses, abrindo espaços para conflitos e disputas políticas ferrenhas que nasceram junto com a República. De forma inicial, tem-se a seguinte passagem no jornal Dezenove de Dezembro (que em 1889 se intitulava órgão do Partido Liberal):

Eis aí a chave do artigo da "República": o órgão republicano preferiria que se fortalecesse a candidatura conservadora.

Não é estranhável isso. No 2o Distrito o sr. Vicente Machado é candidato dos conservadores: e que haverá de novo em que algum conservador da pandilha seja candidato dos republicanos aqui? (MANEJOS, 1889).

Contudo, foi com a maioria do grupo que formava o então Partido Conservador que Vicente Machado iniciou seu domínio político no Paraná. (GOULART, 2014). Ainda que inicialmente tenha atuado somente como deputado estadual, conseguiu nos primeiros anos da República ampliar efetivamente seu poder. Com a deposição dos antigos liberais chefiados por Generoso Marques, Vicente Machado assumiu a liderança da nova organização para a Carta da Constituição Republicana de 1892, em meio a uma Comissão formada por Arthur de Abreu, Alencar Guimarães, Albino Silva e Victor do Amaral. (GOULART, 2014).

Apesar de ter participado da Constituinte anterior (de 1891), este momento tornou-se marco político em sua carreira uma vez que foi a partir dele que seu nome também se destacou nacionalmente como chefe político do Paraná. Afinal, até sua morte, em 1907, procurou se conciliar estrategicamente com os presidentes da República, começando pelo Marechal Floriano Peixoto. A exceção efetiva ocorreu apenas durante a presidência de Prudente de Moraes ${ }^{21}$.

Mas foi durante o governo de Campos Salles que Vicente Machado se estabilizou (mesmo em meio à disputas) como político situacionista importante para o Paraná, tornando-se líder do governo na Câmara Alta. Posição de poder que Ihe conferiu capacidade política de articulação, ampliando capital político cada vez mais significativo e peculiar para consolidação do poder, impedindo que se construísse outra liderança estadual que pudesse fazer frente ao seu nome. Com o objetivo de retratar a postura de Vicente Machado, João Cândido Ferreira o descreveu

21 Em discurso no Senado, Vicente Machado se colocou contra a candidatura de Prudente de Moraes ao Governo Nacional. Jornal A República, em 31 de julho de 1897. 
através das seguintes palavras: "A sua autoridade de chefe incontestável e o seu prestígio de político esperto iam se consolidando no embate das dissensões e controvérsias, que ele habilmente aplacava."22

Como líder do Congresso Legislativo Paranaense (nome dado à Assembleia Legislativa do Paraná - ALEP), foi deputado provincial e estadual por nove mandatos: 1886-1887, 1888-1889, 1891-1892, 1892, 1896-1897, 1897-1898, 1899, 1900-1901, 1902-1903. Nesse ponto, pode-se inferir que o conhecimento do jogo político estabelecido na ALEP e suas regras já estavam claramente compreendidos e internalizados por Vicente Machado, assim como também o reflexo de seu capital político por parte dos demais membros.

Como vice-governador, em 18 de março de 1893, Vicente Machado assumiu o governo do estado do Paraná porque o governador Francisco Xavier da Silva se encontrava afastado por motivo de doença. Sua administração foi marcada por inúmeras dificuldades provocadas pela Revolução Federalista. Quando o embate chegou às terras paranaenses, transferiu temporariamente a capital para Castro, deixou Curitiba sem governo. Vicente Machado reassumiu a direção do estado somente quando a situação de violência já tinha sido controlada pelo florianismo, posicionando-se inteiramente ao lado do Presidente da República e, conforme alguns autores enfatizam, foi acusado de trair ${ }^{23}$ seus próprios conterrâneos. Diante deste quadro, temos o relato:

Não seria, porém, possível a defesa sem apoio eficaz e decidido do Comando do $5^{\circ}$. Distrito Militar a cuja frente estava o gal. Pego Junior.

Transferiu a capital para Castro. Mesmo assim não Ihe foi possível manter o governo legal, dados os precários meios de defesa. Deixou o Estado juntamente com o comandante do distrito a 18 de janeiro de 1894. O governo legal ficou suspenso desde essa data até 12 de abril daquele ano, data em que na cidade de Castro reassumiu o poder, transferindo-se para Curitiba a 05 de maio, quando, sem resistência, os revolucionários abandonavam o Estado. (CARNEIRO, VARGAS, 1987, p. 112).

\footnotetext{
22 Jornal O Dia, em 27 de março de 1924.

${ }^{23}$ O episódio do fuzilamento do Barão do Serro Azul e dos demais membros da Associação Comercial do Paraná ainda precisa ser estudado profundamente. Apesar de várias acusações, mesmo que indiretas, não se pode correlacionar efetivamente o envolvimento de Vicente Machado com o morticínio do km 65.
} 
Quanto a uma possível traição aos paranaenses por tê-los abandonado ${ }^{24}$ no momento mais tenso da invasão maragata, em que provocou a morte do Barão do Serro Azul| ${ }^{25}$, Vicente Machado declarava que fez o que estava ao seu alcance para impedir a entrada dos federalistas e que sua autoridade estaria sem sustentação suficiente, sendo inútil realizar combate direto. Posteriormente, durante vários discursos procurou se retratar e justificar suas ordens durante o governo em substituição à Xavier da Silva.

Eleito em 1895, ocupou cadeira no senado ${ }^{26}$ até o ano de 1902. O interessante é que o cargo no senado não o impediu de eleger-se e participar, quase que ininterruptamente, como deputado estadual na ALEP até 1903, ano em que iniciou sua campanha política para o executivo do estado. (GOULART, 2014).

Em 1904 assumiu a direção do Paraná, elegendo-se sem nenhuma dificuldade pelo Partido Republicano Federal, pois soube utilizar da máquina pública que já era controlada por seu partido político, assim como se valeu fartamente dos mecanismos das fraudes eleitorais, estratégias frequentes na época. (GOULART, 2014). No que diz respeito às suas realizações como governador, criou o primeiro Banco Comercial, arrendou a Estrada de Ferro do Paraná, construiu a rede de esgotos e abastecimento de água ${ }^{27}$ em Curitiba, melhorou as condições dos sentenciados,

${ }^{24}$ Como descrição da "fuga" de Vicente Machado, Rocha Pombo apresenta a referida situação: "O dia 18 amanhecera lúgubre (...). O outeiro de São Francisco, bem como nos dias 16 e 17, está tomado pela multidão ansiosa. Toda a vida de Curitiba estava suspensa. As próprias repartições públicas não funcionavam mais. 0 comércio a certas horas do dia fechava todo, e à noite, só havia nas ruas o bulício dos numerosos grupos que comentavam os acontecimentos. À tarde desse dia 18, observa-se nas ruas um movimento extraordinário, especialmente de cavaleiros. Ao pôr-do-sol, o vice-governador, a cavalo, de bombachas e seguindo ordenanças, atravessava a galope diversas ruas (...). Todos acreditavam que ia travar-se fora da cidade a resistência de morte, (...). Ao anoitecer, porém, a população desafogouse: o combate não se daria; o vice-governador tinha preferido, e nisso foi muito bem aconselhado, retirar-se para São Paulo com um piquete de amigos e funcionários. (POMBO, 1980).

${ }^{25}$ Durante várias edições no ano de 1924 o Jornal Gazeta do Povo registrou o esforço sobre humano do resgate do corpo (restos mortais) do Barão do Serro Azul - Ildefonso Pereira Correia -, bem como dos demais neófitos. Depois do tiroteio que resultou sua morte, o nobre foi enterrado no local do assassinato, na Serra do Mar. Um ano após o acontecimento, à pedido da família e de alguns amigos (entre eles seu sócio, David Carneiro), um grupo de homens e caboclos juntaram-se para fazer o resgate do corpo, situação que durou vários dias em meio às dificuldades geográficas e também pelo impedimento colocado pelas autoridades da época (1895). Para resumir tal história, que apesar de mórbida é muito interessante, vale apontar que durante o trajeto da Serra do Mar até o Cemitério Municipal de Curitiba, São Francisco de Paula, seu corpo teve que ser escondido e carregado como se fosse sacos de erva-mate, além do fato de que o registro histórico (Termo de Inumação) revela que o sepultamento só pode ocorrer durante a noite, no mais absoluto sigilo. (Jornal Gazeta do Povo, 1924). Conferir Poliana MILAN, 2010.

${ }^{26}$ Membro das Comissões de Constituição, Poderes e Diplomacia, Marinha, Guerra e Finanças.

27 Para essa discussão, vale conferir o importante texto de Marcus Roberto de Oliveira (2016). 
aprimorou a viação e regularizou o serviço comercial. A Lei n. 449, de 24 de março de 1902, de equiparação dos impostos de exportação de erva-mate bruta e beneficiada foi de sua autoria.

Suas ações e estratégias políticas foram seguidas por seus sucessores. Em meio a aliança partidária entre os antigos oponentes pica-paus (florianistas) e maragatos (federalistas), de 1908, o Paraná continuou seguindo os parâmetros da política nacional, procurando sempre compor com a situação federal, posicionamento político engenhoso que foi anteriormente desenhado pelo comando de Vicente Machado. Em se tratando de suas ações, enquanto chefe do executivo estadual para com os membros do congresso legislativo, verificou-se a submissão da ALEP por meio da aprovação de seus projetos e da escolha dos candidatos, fato que ocorria até mesmo em relação àqueles que pertenciam à agremiação opositora. (GOULART, 2014). Contrariando muitos de seus discursos que enfatizavam as determinações constitucionais da liberdade de voto e quanto à garantia de um terço da minoria (oposição) para composição dos 30 membros da ALEP, o resumo biográfico de seu aliado político, João Cândido Ferreira, expressa o seguinte:

Como preito à representação da minoria, consoante o Dispositivo Constitucional, ele tinha concedido o terço ao partido oposicionista: este, em vez de contentar-se com os 10 deputados que lhe eram garantidos, apresentou chapa com 20 nomes ao sufrágio de seus correligionários.

Então Vicente Machado, para vingar aquela demasia, escolheu entre os candidatos da oposição os 10 que, ao seu critério de chefe adverso, lhe pareceram mais dignos e mandou derivar uma forte votação a esses preferidos [grifo nosso].

Assim, conseguiu, num pleito libérrimo, eleger todos os seus amigos indicados e ainda escolher, na chapa de oposição, os 10 candidatos que bem entendeu [grifo nosso]. Deste fato o Congresso do Estado ficou organizado de inteira conformidade com sua vontade inflexível. ${ }^{28}$

Vicente Machado firmou-se também na direção do jornal $A$ República (que era órgão oficial do PRF). Junto com Pedro Lessa e Júlio de Mesquita, deixou vários artigos sobre política e também textos (discursos) fundamentando sua defesa quanto aos acontecimentos da Revolução Federalista. Também soube utilizar os jornais e tribuna da ALEP para atacar seus oponentes locais, sobretudo Generoso Marques dos Santos e Afonso Camargo, líder do Partido Republicano oposicionista e seu fiel pupilo (ao menos até 1908), respectivamente.

\footnotetext{
28 Jornal O Dia, 27 de março de 1927.
} 
Em termos gerais, a concentração de poder e o controle do jogo político no cenário paranaense foi fruto da postura conflituosa e combativa de Vicente Machado em relação aos seus opositores ${ }^{29}$ diretos, e também para com aqueles que pretendiam compartilhar de seu poder. Vale ressaltar mais um aspecto da descrição que João Cândido Ferreira faz de Vicente Machado: "Enérgico, até a violência, quando deparava em seu caminho qualquer obstáculo ${ }^{30}$ que o impedisse de avançar na conquista de um ideal alcanforado [sic]; era dócil, tolerante e até carinhoso, alcançada que fosse a chanaan [sic] indicada por seu patriotismo." 31

Vicente Machado pertenceu à primeira geração dos governadores republicanos no Paraná. Até sua morte existiram efetivamente dois partidos políticos disputando as eleições (configurados em 1897), Partido Republicano Federal (vicentista - e, portanto, situacionista) e o Partido Republicano (oposicionista, sob a liderança de Generoso Marques). Muito se tentou em termos de se diminuir a importância política do vicentismo, mas ao movimento oposicionista era conferido apenas alguns municípios e, no máximo, dez cadeiras na ALEP. Somente em 1908 os representantes de ambas agremiações formaram o Partido Republicano Paranaense, sob o comando (construído severamente) de Afonso Camargo.

\section{AMPLIAÇÃO DE CAPITAIS POLÍTICOS E ECONÔMICOS: APONTAMENTOS PRELIMINARES SOBRE} OS SOGROS DE VICENTE MACHADO

\subsection{Antonio Moreira Lima}

\footnotetext{
${ }^{29}$ Muitos de seus oponentes foram cooptados em algum momento político importante. Porém, outros expressaram fortemente sua rivalidade política como o ex-deputado gaúcho Fagundes Varella, que durante os primeiros anos do século XX aliou-se ao grupo de Generoso Marques e fez uma série de críticas e denúncias abertas na imprensa da época. (GOULART, 2014).

${ }^{30}$ Em 1890 Vicente Machado declarou seu rompimento político em relação a administração do governo provisório de Américo Lobo Leite, mas isso ocorreu porque a substituição do referido governador havia sido declarada ao situacionismo local (que na época estava ao lado de Generoso Marques) pelo executivo federal. Já Américo Lobo Leite declarou que se colocou contra a reforma do ensino proposta por Vicente Machado, como também não concordava com a contratação de vários delegados de ensino, os quais eram amigos e aliados do chefe político paranaense. Jornal Diário do Paraná, em 31 de julho de 1890.
}

31 Jornal O Dia, em 27 de março de 1924. 
Antonio Moreira Lima ${ }^{32}$, sogro do primeiro casamento de Vicente Machado. Filho do cap. Francisco José Antunes Lima e de Gertrudes Cypriana de Camargo. Nasceu em Itatiba, em 1817. Faleceu em 28 de março de 1878, em Itatiba, conforme o jornal Diário de S. Paulo:

Informaram a Gazeta de Campinas que anteontem faleceu repentinamente em Itatiba o Major Antonio Moreira Lima, sogro do dr. José Machado Pinheiro Lima, deputado provincial. Era o fazendeiro mais importante daquela localidade, e o que mais concorreu para muitos melhoramentos na cidade, segundo a mesma gazeta. O Diário, dando esta notícia, diz que a morte foi repentina, exalta as distintas qualidades do finado e acrescenta: 'Era conservador, mas os adversários políticos fizeram-lhe justiça, tributandoIhe merecida justiça.' Nossos pêsames ao sr. Dr. Pinheiro Lima e toda a família. (FALECIMENTO, 1878).

Antonio Moreira foi capitão na Guarda Nacional, em Bethlém de Jundiahy (também com a grafia Belém), - depois Itatiba - em 1868. (GUARDA, 1868). No que tange aos seus recursos econômicos, era proprietário de 'fazenda de café e de escravos ${ }^{33}$.

No ano de 1872 foi agraciado com "privilégio exclusivo por 90 anos", junto com Camilo José Pires, Antonio Alves Cardoso, Florencio Corrêa Pupo da Silveira, Bento Pires de Avila, Pedro Soares Penteado, Dr. Tomé Pires de Avila Neto, Julio Joly Jr. ${ }^{34}$ e Eugênio Joly, para construir uma estrada de ferro de bitola estreita que partiria da Vila de Bethlém de Jundiahy até a estrada de ferro de Jundiahy, tendo como destino a cidade de Santos. (LEIS PROVINCIAIS, 1872).

Participou da Comissão Censitária de São Paulo como membro importante, junto com o Vigário Joaquim Theodoro de Araújo Tavares, Julio Joly Junior, Dr. Tomé Pires de Avila Netto e Alexandre Rodrigues Barbosa. (COMISSÕES CENSITÁRIAS, 1873).

Em se tratando de sua genealogia, Leme (1905) aponta os seguintes laços de parentesco:

\footnotetext{
32 Esta genealogia será atualizada posteiormente.

33 "Fugiu no dia 17 de março do corrente ano, da fazenda de Antonio Moreira Lima do Bethlém de Jundiahy, o escravo Gabriel crioulo da Vila de Jaguary, província de Minas, com os seguintes sinais: Cor preta, corpo regular, bem barbado e muito ladino, altura regular, boa dentadura, idade mais ou menos de 32 anos, trabalha em todo serviço de lavoura e um pouco de pedreiro, e já foi cozinheiro do Padre Sanches em Jaguary. Desconfia-se que fosse para os lados de Botucatu onde consta estarem residindo seus antigos senhores moços. Gratifica-se generosamente a quem o capturar ou der notícia exata. Assim como protesta-se punir com os rigores da lei a quem o açoutar. Bethlem de Jundiahy, 24 de março de 1874. Antonio Moreira Lima." (FUGIU, 1874).

${ }^{34}$ Genro de Antonio Moreira Lima, sua filha, Olympia Moreira, era casada com Julio Joly, irmão de Eugênio Joly. (GENEALOGIA PAULISTANA, 1905).
} 
* 1o casamento: com Constança Eliza de Camargo Alves, filhos:

1. Olegário Moreira Lima, c/c (significando casado(a) com ou casou-se com) Maria das Dores Alves, viúva de Antonio Alves Galvão;

2. Olympia Moreira Lima, c/c Julio Joly. Tiveram os filhos;

2.1. Maria Olimpia de Moura, c/c seu primo Ten. Cel. Eduardo Alves de Moura

(filho de Eduardo Alves de Moura e de Idalina Carolina de Brito);

2.2. Arthur Joly, solteiro em 1900;

2.3. Fausto Joly, solteiro em 1900;

2.4. Octávio Joly, solteiro em 1900;

3. Horácio Moreira Lima, Maria (?), filha de Francisco Lourenço da Rocha e de sua primeira mulher Carolina Alves;

3.1 Antonia, c/c Oladim Eugênio;

4. Francisca, foi c/c seu tio João Alves Cardoso (irmão de sua mãe);

5. Emília Moreira Lima, primeiramente foi c/c José de Assis Valle (filho do cap. Assis Valle e de Maria Joana), o segundo casamento foi com (?);

6. Máxima Moreira Lima, c/c dr. José Machado Lima - irmão de V.M. - bacharel em Direito, Deputado e Ministro do Tribunal de Justiça de São Paulo. Filhos:

6.1. José Máximo Pinheiro Lima, bacharel em Direito, juiz de Direito da Comarca de Sto. Antonio da Cachoeira em 1903;

6.2. Dr. Mario Gracho Pinheiro Lima, formado em Medicina;

7. Joaquina Moreira Lima, c/c Gabriel José Rodrigues de Castro (filho de Manoel José de Castro);

8. Emygdio Moreira Lima, c/c Maria (filha de Paulino Bueno de Aguiar e de Idalina Carolina de Brito);

9. Maria Antonia Moreira Lima (Maria Antonia Moreira Machado Lima), em 1882 c/c Vicente Machado. Seus filhos:

9.1. Caio Gracho,

9.2. Antonio Jorge,

9.3. Vicente Machado Junior,

9.4. Valentina,

9.5. João, 
*2o casamento: com Jacintha de Brito Lima, filhos:

1. Antonia Moreira de Lima, c/c Tranquilino Alves Galvão. Filhos:

1.1. Lucilia Moreira Glavão;

1.2. Tranquilino Moreira Galvão;

1.3. Ralpho Moreira Galvão;

1.4. Fabio Moreira Galvão;

1.5. Osmany Moreira Galvão;

2. Jorge Moreira Lima.

\subsection{Joaquim Antonio de Loyola}

Joaquim Antonio de Loyola, sogro do segundo casamento de Vicente Machado. Foi importante industrial e negociante de erva-mate no Paraná ainda nos tempos do império.

Suas atividades políticas também começaram antes da República. No ano de 1876 exercia a atividade de vereador no município de Porto de Cima. (VEREADORES, 1876). Consta que no mesmo ano era subdelegado no distrito policial de São João da Graciosa, em 1876. (DISTRICTO, 1876).

Em 1884 rescindiu contrato como empreiteiro de conservação de uma secção da estrada da Graciosa. (PAGAMENTO, 1884).

Suas relações e prestígio político proporcionaram-lhe, em 1883, junto com João Tobias Pinto Rebello e José Pinto Rebello, a concessão da Assembleia Provincial para o estabelecimento de bondes destinados ao transporte de passageiros e cargas em toda cidade de Curitiba. O fim da referida sociedade ocorreu em 1887. (PRIMEIRA, 1887). Nessa mesma época foi nomeado primeiro juiz de paz da paroquia de Antonina. (LICENÇAS, 1887).

Ainda no mesmo ano, seu nome constava na lista dos 87 acionistas da Companhia Alimentária [sic], sendo eleito membro do Conselho Fiscal, (A PEDIDO, 1887).

Em 7 de dezembro de 1889 foi criada no Paraná a Liga Patriótica dos Paranaenses. Organização cujo fim era levantar recursos para pagamento da dívida interna dos Estados. 
Formada por um grupo seleto de paranaenses, tinha como presidente Presciliano da Silva Correia,

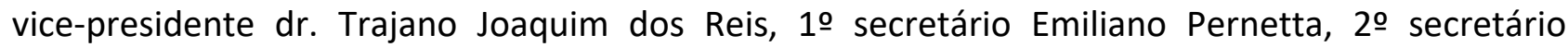
Joaquim Vergolino Gomes Barbosa, tesoureiro João Taborda e orador José Francisco da Rocha Pombo. Joaquim Loyola não estava presente no respectivo evento, porém, seu nome constava na Comissão responsável pelo município de Antonina: Dr. Francisco Machado Beltrão, Joaquim Antonio de Loyola, Benigno Pinheiro Lima (tio de Vicente Machado), Joaquim Barnabé Linhares, José de Assis Teixeira e Salvador Paladino. (LIGA, 1889).

Conforme destacado anteriormente, durante início do regime republicano foram feitas tentativas de se criar um único partido no Paraná, assumindo-se como Partido Republicano. Para cumprir este objetivo, foram criadas comissões municipais. Joaquim Antonio de Loyola aparece como membro da Comissão de Antonina, tendo como demais membros da comissão: Joaquim Manoel Ribeiro Vianna, Joaquim Barnabé de Linhares, José Francisco de Oliveira Marques e João Cristóvão da Silva. (PARTIDO, 1889).

Em fevereiro de 1890 Joaquim Loyola foi eleito vice-presidente do Clube Republicano de Antonina (e João Manoel Ribeiro Vianna, o presidente). A finalidade do clube seria divulgar e "vulgarizar" as ideias políticas e sociais professadas pelo Clube Republicano da Capital. (CLUB, 1890).

Na mesma época, fevereiro de 1890 , foi nomeado como um dos vogais (membros) da Intendência Municipal de Antonina, uma vez que algumas câmaras municipais tinham sido dissolvidas pelo Decreto n. 28 de janeiro de 1890, baseado no Decreto n. 3 de 11 de dezembro de 1889, em nome do então governador (provisório) do Paraná, contra-almirante José Marques Guimarães. Para composição da respectiva Intendência, constavam os seguintes nomes: presidente- Ten. Cel. João Marques Ribeiro Vianna, vice-presidente - José Francisco de Oliveira Marques. Vogais: Joaquim Barnabé de Linhares, João Cristovão da Silva, Joaquim Antonio de Loyola, José Maria da Costa e Benigno Pinheiro Lima. (DECRETO N.28, 1890). Contudo, o jornal $A$ República aponta que Joaquim Loyola não teria aceitado sua nomeação para vogal da Intendência de Antonina, apresentando o nome de Arthur Victor de Sá como seu substituto mediante nomeação do governador. (INTENDENCIA, 1890).

Joaquim Loyola foi Coronel da Guarda Nacional, pela comarca de Antonina. Residia nesta cidade no ano de 1891, local onde se tornou expressivo chefe político. Em outubro de 1892 foi eleito para o conselho fiscal durante a assembleia de instalação do Banco do Paraná. (BANCO, 
1892). Pouco tempo depois, iniciou suas atividades políticas como deputado estadual a Assembleia Legislativa, participando dos seguintes biênios: 1894-1895, 1896-1897, 1898-1899, 1900-1901, todos pelo Partido Republicano Federal, agremiação dirigida por Vicente Machado.

Era maçom. Joaquim de Loyola participou da Loja Acácia Paranaense n. 0705, fundada em 1900.

Foi coletor de Rendas de Curitiba (nomeado em 1901). Um ano depois, 1902, eleito delegado do Partido Republicano Federal. No ano de 1903 foi mesário na 4a secção da capital para eleição de um senador, quatro deputados federais (para o período de 1903-1906) e vicepresidente da República. (EDITAIS, 1903).

Em 1908 tirou dois meses de licença para tratamento de saúde - Decreto n. 667. (VÁRIAS NOTÍCIAS, 1908). No ano de 1910 o então governador Francisco Xavier da Silva (pelo decreto n. 348) concedeu um ano de licença, com os respectivos vencimentos, ao coletor Cel. Joaquim A. de Loyola - época que viajou para a Europa com sua família e a família de sua filha, viúva de Vicente Machado, para tratamento de saúde. (NOTAS, 1910). "Partiram hoje para a Europa o sr. Coronel Joaquim Antonio de Loyola com sua exma. família, e a exma. viúva do dr. Vicente Machado com seus filhos." Ficaram quase dois meses - chegaram em 29 de maio de 1910. (HOSPEDES, 1910)

Joaquim Loyola faleceu em 27 de dezembro de 1918, em Curitiba. (NíCOLAS, 1984, p. 205).

Joaquim Antonio de Loyola nasceu em Morretes, a 25 de dezembro de 1847. Membro de família tradicional do Paraná, sua genealogia consta tanto na Genealogia Paulistana (1905) quanto na Genealogia Paranaense. (NEGRÃO, 1926).

Filho de João de Loyola e Silva e de Benedita dos Prazeres Loyola. Seus filhos (irmãos de Joaquim A. Loyola), segundo Leme (1905) e Negrão (1926):

1. Vicente Ferreira de Loyola: importante industrial de Morretes. Foi c/c Luiza do Nascimento Loyola (filha de Manoel Ricardo do Nascimento e de Maria Caetana de França). Filhos:

1.1. Brasilio de Loyola;

1.2. Guilhermina de Loyola, c/c Cel. Amazonas de Araújo Marcondes, importante chefe político de União da Vitória. Além de prefeito e deputado estadual (1891-1892, 1910-1911, 19141915, 1918-1919, 1922-1923); (prima de Helena de Loyola).

1.3. Argemiro de Loyola, c/c Targina de Oliveira Loyola; 
1.4. Maria de Loyola, c/c seu tio Agostinho de Loyola, que nasceu em 1849 e faleceu em 1899 (sendo a primeira esposa). Empregado de fiscalização de rendas do Estado. Filhos:

1.4.1. Leôncio Laurentino de Loyola, casado com Maria Luiza Monteiro de Loyola. Filhos: Maria de Lourdes; Francisco;

1.4.2. Vicente Loyola, casou-se em 1901 com Carmella Bevilacqua. Filhos: Maria Luiza de Loyola, que se casou com Mario Antunes em 1923; Nair de Loyola Alice, casada com Armando Alice, em 1926; Dinah;

1.4.3. Julia Alice de Loyola, casada em 1909 com Oliveiro Monteiro Junior;

1.5. Julia de Loyola, professora, a segunda esposa de Agostinho de Loyola, seu tio. Casaram-se em 1888. Filhos:

1.5.1. João Argemiro de Loyola, em 1919 c/c Maria da Glória Saldanha de Loyola. Filhos: Agostinho; Acyr.

1.5.2. Tenente Humberto Agostinho de Loyola, em 1915 c/c Romilda Azevedo de Loyola. Filha: Diva, nascida a 11 de dezembro de 1918;

2. Agostinho Ferreira de Loyola, c/c Maria e, depois, com Julia (ambas sobrinhas, citadas acima);

3. Cel. Joaquim Antonio de Loyola, c/c Guilhermina dos Santos Loyola (filha de José Antonio dos Santos e de Francisca Maria da Luz). Filhos:

3.1. Ten. Cel. Lauro do Brasil Loyola, c/c Anna Emília Soares (filha de Antonio Soares Gomes e de Maria Julia Soares). Comerciante, Prefeito de Antonina pelo PRF. ALEP/ deputado estadual: 1908-1909, 1910-1911, 1912, 1913, pelo PRPr. Filhos:

3.1.1. Ismenia;

3.1.2. Raul;

3.1.3. Ruth;

3.1.4. Ruy;

3.1.5. Rachel;

3.1.5. José Guilherme;

3.2. Dr. José Guilherme de Loyola, nascido em 1874, médico, c/c Maria Augusta Carneiro de Loyola em 1903 (filha de David Antonio da Silva Carneiro, abastado capitalista, e de 
Olympia da Costa Carneiro). ALEP/ deputado estadual: 1902-1903, 1904-1905, 1906-1907, pelo PRF. Filhos:

\subsubsection{Maria José;}

3.2.2. Dr. José Maria Carneiro de Loyola, engenheiro civil pela Universidade do Paraná, formado em dezembro de 1925;

3.2.3. Lauro Carneiro de Loyola, funcionário bancário;

3.2.4. Odete;

3.3. Helena de Loyola Machado Lima, segunda esposa de Vicente Machado. Filhos:

3.3.1. Laura Loyola Machado Lima;

3.3.2. Vicente, falecido;

3.3.3. Sarah Machado Cavalcanti, c/c Léo Carlos Cavalcanti, indicado anteriormente;

3.3.4. Gastão de Loyola Machado Lima;

3.3.5. José, falecido;

* Do segundo casamento de Helena de Loyola Machado Lima, com José Bento Lamenha Lins (descrito anteriormente). Teve: Helena; Adolpho;

3.4. Joaquim dos Santos Loyola, falecido;

3.5. Aline dos Santos Loyola, c/c Heitor Pires de Carvalho e Albuquerque, capitão do exército. Filhos:

3.5.1. Walter;

3.5.2. Yolanda, falecida;

\subsubsection{Nelson;}

3.5.4. Yeda;

3.6. Joaquim Antonio dos Santos de Loyola Filho - faleceu em 1952, conhecido como Quinco. Médico, clinicou em Castro e Ponta Grossa, c/c Haydee Fonseca de Loyola. Filhos:

3.6.1. Renê Fonseca de Loyola, c/c Orlando Teles;

3.6.2. Arlente [sic] Fonseca de Loyola, c/c dr. Alberto Capanema. Filhos: Maria Helena e Luiz Fernando; (ANTONIO, 1952).

3.6.3. Wilson Fonseca de Loyola, militar. Nascido em 1921. Faleceu em 31 de outubro 2016, aos 95 anos de idade. Foi casado com Idália Cordeiro de Loyola; 
4. Antonio Ferreira de Loyola, c/c Rosa Luiza de Bittencourt Loyola. Filhos:

4.1. Joaquim de Bittencourt Loyola;

4.2. Castorina Loyola, falecida, c/c Bernardo Silvo;

4.3 Leocadia Loyola, c/c Bernado (seu cunhado). Filhos:

4.3.1. Emília Loyola, c/c Joaquim Duarte Camargo. Filhos:

Maria Cândida; José; Antonio;

5. José Ferreira de Loyola, c/c Maria Rosa de Bittencourt. Filhos:

5.1. Arthur Ferreira de Loyola, nascido em 1862, professor, c/c Domitila Moura de Loyola, filha do cap. Augusto Ferreira de Moura e de Porcina Borges de Moura. Filhos:

5.1.1. Dr. Leonidas de Loyola, advogado, c/c Edith do Nascimento Loyola. Filhos: Carlos Eduardo, falecido; José Antonio;

5.1.2. Dr.Levy de Loyola, médico, falecido em 2 de julho de 1922;

5.1.3. Marília, falecida na infância;

5.2. Major João Pedro Ferreira de Loyola, c/c Maria Rosa Loyola. Filhos:

5.2.1. Ocrayna de Loyola, c/c Ascendino Ferreira do Nascimento, filho do cel. Ascendino Ferreira e de Emília Alves do Nascimento. Filhos: Boabidil Ferreira do Nascimento; Fernando Ferreira do Nascimento;

5.2.2. Percilval Loyola, c/c Anita Romero Loyola, em 1924, filha de João Pedro Romero e de Hyppolita Alves Vieira Romero. Filhos: João, Eraylde;

5.2.3. Marina;

5.2.4. Nelma;

5.3. Honorina Loyola, casada com Victorino Bacellar Filho. Tiveram:

5.3.1. Zeneida;

5.3.2. Maria Rosa;

5.3.3. Zeno Bacellar;

5.3.4. Aroldo;

5.3.5. Cecília;

5.3.6. Moacyr Bacellar; 


\subsubsection{Manoel;}

5.3.8. José;

5.4. Maria Clara Loyola da Silveira, nascida em 1865, c/c Cassiano da Silveira em 1880. Filho de Manoel Lopes Trigo e de Maria Correia Silveira, ambos de São Paulo Filhos:

5.4.1.Ezaú Silveira, c/c Alice Breyne, filha de Afonso de Breyne e de Alzira de Breyne. Filhos: Oswaldo; Ivette; Paulo; Maria de Lourdes; Roberto; Ilza; Gilberto;

5.4.2. Abismael Silveira, c/c Albertina Neves da Silveira;

5.4.3. Sarah Silveira;

5.4.4. Laura Silveira Cyrne, c/c José Alcides Cyrne, filho de José Cyrne e de Anna Adélia Cyrne. Filho: Helio;

5.4.5. Apoll Silveira, falecido, c/c Dora Silveira, filha de João Saltine e de Eliza Saltine. Filhs: Dory.

5.4.6 Rachel Silveira da Costa, c/c. Antonio Rodrigues da Costa, filho de Antonio Rodrigues da Costa e de Maria Luiza Rodrigues da Costa. Filhos: Aroldo; Alberto;

5.5. Lucio de Loyola, casado com Augusta Martins de Loyola, filha de Bento Martins Coelho e de Maria Francisca Martin. Filhos:

5.5.1. Eudoxia;

5.5.2. Nathália;

5.5.3. Marieta Loyola, casada com Francisco Soares Raposo. Filha: Neuza.

5.5.4. Lucio;

5.5.5. José;

5.5.6. Sylvia, falecida;

5.5.7. Maria de Lourdes;

5.5.8. Luiz Felipe;

5.6. Theóphilo Ferreira de Loyola, c/c Francisca de Oliveira Ribas Loyola. Filha de Francisco de Oliveira Sá Ribas e de Maria do Carmo Ribas. Filhos:

5.6.1. Maria do Carmo Loyola Guimarães, c/c Clovis Baptista Guimarães;

5.6.2. Cecília Loyola;

5.6.3. José Ribas de Loyola;

5.6.4. Maria Francisca Ribas de Loyola; 
5.6.5. Maria Christina Ribas de Loyola;

5.6.6. João Ribas de Loyola;

5.6.7. Maria Rosa Ribas de Loyola;

5.6.8. Maria de Lourdes Loyola;

5.6.9. Maria da Aparecida Loyola;

Teve mais três filhos falecidos;

6. Maria Benedita de Loyola, falecida em novembro de 1908, c/c José Celestino de Oliveira. Filhos:

6.1. Targina Loyola de Oliveira, c/c seu primo Argemiro Ferreira de Loyola. Segundo casamento com Olavo Guimarães Corrêa;

6.2. José Celestino de Oliveira Junior, jornalista, redator chefe do Diário da Tarde de Curitiba. Casado com Augusta Rodrigues de Oliveira, filha de Antonio José Rodrigues e de Maria da Gloria Tinoco. Filhos:

6.2.1. Aracy de Oliveira Riedel, nascida em 1892, c/c o professor Hugo Oswaldo Riedel, da Faculdade de Farmácia da Universidade do Paraná. Foi tabelião em Blumenau. Filhos: Diva de Oliveira Riedel, nascida em 1911; Oswaldo de Oliveira Riedel, nascido em 1913; Juracy de Oliveira Riedel, nascida em 1918;

6.2.2. Argemiro Celestino de Oliveira, negociante no Rio de Janeiro, nascido em 1893, casado em 1925 com Laura Capelline;

6.2.3. Maria da Glória, nascida em 1824, c/c Alcebíades da Penha Lima. Filhos: Cilly; Orlando;

6.3. Capitão João Celestino de Oliveira, falecido em 1924, c/c Celmira Freitas de Oliveira, filha de Antonio do Valle e de Maria Paim de Oliveira. Filhos:

6.3.1. Geny de Oliveira Piffero, nascida em 1890, c/c Bernardo Piffero, em 1907;

6.3.2. Cecy Freitas de Oliveira, solteira;

6.3.3. Edgard Freitas de Oliveira, nascido em 1896, c/c Laura Souza e Mello de Oliveira. Filhos: Geysha Mello de Oliveira; Antonio Carlos Mello de Oliveira;

Bandeira, em 1925;

6.3.4. Suely de Oliveira Assis Bandeira, nascida em 1898, c/c Henrique Assis 
6.3.5. Parminio Freitas de Oliveira, nascido em 1903;

6.3.6. Maria da Conceição Freitas de Oliveira, solteira;

6.4. Major Brasílio Celestino de Oliveira, c/c Maria José de Oliveira em 1904, filha de Antonio de Oliveira e de Emília Nobrega de Oliveira. Filhos:

6.4.1. Fany celestino de Oliveira, solteira;

6.4.2. Targina Celestino de Oliveira;

6.4.3. Brasílio celestino de Oliveira, nascido em1911;

6.4.4. Alceu Celestino de Oliveira, nascido em 1913;

6.4.5. Maria da Graça;

6.4.6. Odette Celestino de Oliveira;

** Filho fora do casamento: 6.4.7. Celso Celestino de Oliveira, nascido em

1905;

6.5. Maria Francisca Celestino de Oliveira, solteira;

6.6. Capitão Victor Celestino de Oliveira, c/c Rita Gomes de Oliveira, filha de João Gomes de Oliveira e de Rosa Gomes de Oliveira. Filhos:

6.6.1. Aracy Celestino de Oliveira, solteira;

6.6.2. Ernani Celestino de Oliveira, nascido em 1905, solteira;

6.6.3. Avany Celestino de Oliveira, solteira;

6.7. Carmem Celestino de Oliveira, c/c desembargador Dr. Augusto Leonardo Salgado Guarita. Filhos:

6.7.1. Ernani de Oliveira Guarita, nascido em 1899, solteiro;

6.7.2. Raif de Oliveira Guarita;

6.7.3. Orville de Oliveira Guarita;

6.7.4. Jandyra de Oliveira Guarita;

6.7.5. Stella de Oliveira Guarita;

7. Manoel Ferreira Cordeiro de Loyola, c/c Cândida de Souza Loyola, filha de Luiz Maria de Souza e de Dulce Luiza Gomes. Filhos:

7.1. Maria Rosa, falecida; 


\subsection{João Saturnino, falecido;}

7.3. João Luiz, falecido;

7. 4. Dulce de Loyola, diplomada pela Escola Normal de Curitiba, professora de trabalhos e prendas da escola Normal;

7.5. Maria Guilhermina, falecida;

7.6. Zulmira, falecida;

7.7. Francisco, falecido;

7.8. Manoel José, falecido;

Como se pode notar, a família Loyola foi muito extensa durante o contexto do Paraná da República Velha. Ainda hoje possui membros ocupando cargos importantes no estado. A atualização deste ramo familiar também será desenvolvida posteriormente.

\section{CONSIDERAÇÕES FINAIS}

Embora o objetivo do presente texto seja apontar notas iniciais da biografia que ainda está por ser feita, buscou-se frisar alguns traços de personalidade do referido governador segundo alguns contemporâneos e também destacar os capitais que Vicente Machado recebeu de sua família e por meio de seus casamentos. Muitas contradições são apresentadas pela imprensa paranaense acerca do perfil de Vicente Machado, contudo, não se pretende construir juízo de valor sobre o comportamento do mesmo, - até porque como insiste Bourdieu (1998), as organizações textuais de biografias não passam de ilusões se forem pensadas com o peso exclusivo na vida do indivíduo. Não podemos deixar de salientar que Vicente Machado representou ser agente social de sua época, emaranhado em estruturas e relações de poder condizentes com o fim do Império e início da República. Assim, sua figura o relaciona ao ator político inspirado no governante que tem como objetivo chegar ao poder e mantê-lo em suas mãos, o mais próximo do que caracteriza um político astuto no sentido maquiavélico. (MAQUIAVEL, 1995). 
Apesar de ter emplacado uma série de inimigos, alcançou boa parte de seus propósitos enquanto político paranaense da República Velha, bem como também foi o nome mais citado em toda imprensa estadual, exaltando-o como exemplo a ser seguido pelas demais gerações, e ao mesmo tempo também classificado por seus pares e rivais como político autoritário e contraditório, que não se deve valer de forma alguma de modelo ético. Mesmo diante das divergências impostas pelos acontecimentos da Revolução Federalista, Vicente Machado construiu seu "consulado"35. Mais do que uma imensa fortuna dividida entre terras, prédios, fazendas, dinheiro em vários bancos nacionais e estrangeiros, ações, apólices, obrigações de empréstimos, títulos de dívidas, Vicente Machado deixou várias lições de práxis política para seus descendentes e um imenso capital simbólico. (TESTAMENTO, 19070. Teve câncer de garganta ${ }^{36}$ e faleceu precocemente numa manhã curitibana, a 3 de março de 1907, não cumprindo integralmente seu almejado mandato de presidente do estado do Paraná.

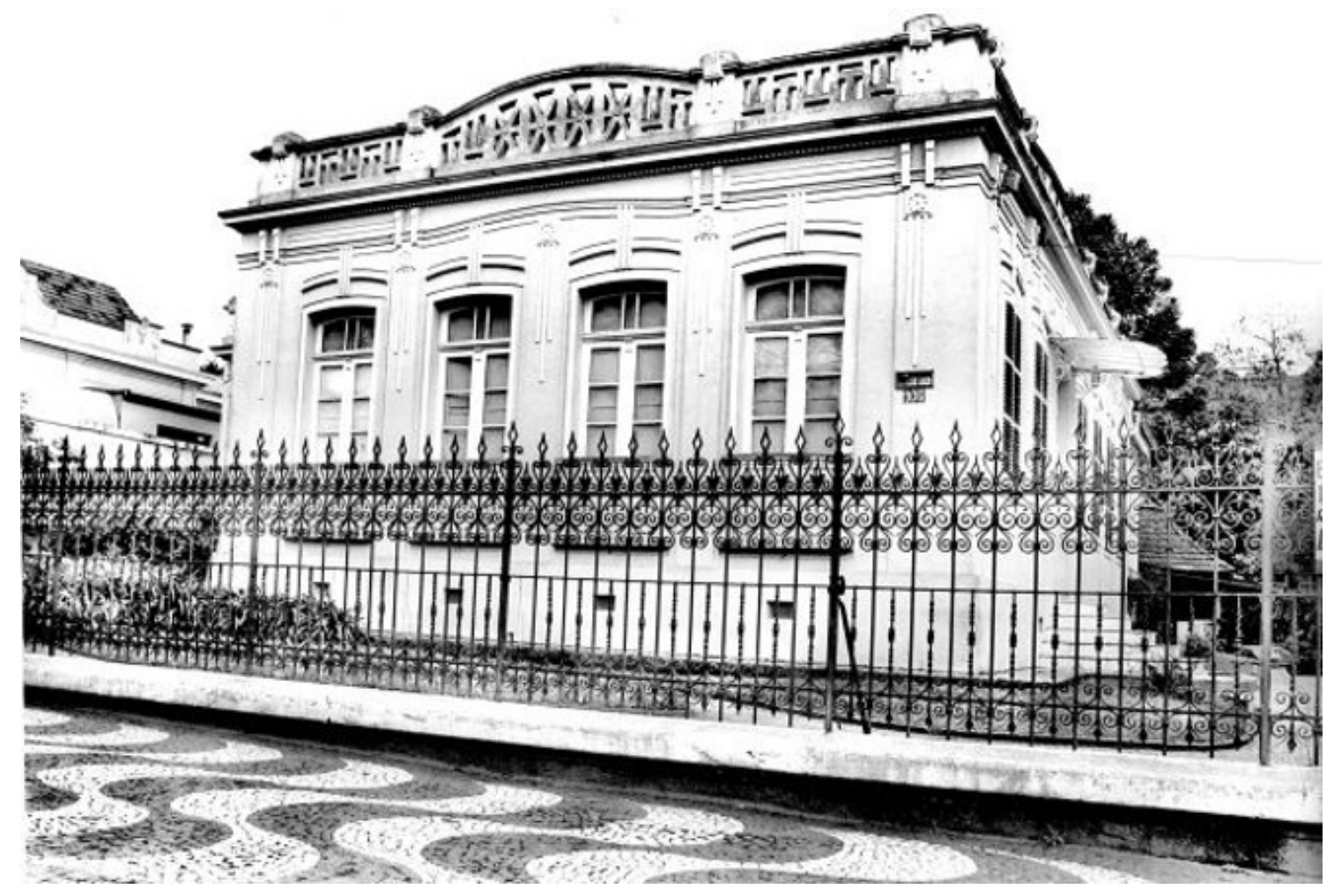

\footnotetext{
${ }^{35}$ Conforme aponta Sêga, termo preciso para indicar a liderança e as estratégias concebidas por este ator político. (SÊGA, 2005).

${ }^{36}$ O longo tempo acamado pela doença permitiu à sua esposa, Helena de Loyola, construir um anexo nos fundos de sua casa, para que seu corpo fosse velado e permitisse receber as várias homenagens.
} 
Fonte: Gazeta do Povo, acervo Cid Destefani. Casa de Vicente Machado, deixada em testamento para sua esposa Helena de Loyola. Rua Comendador Araújo, onde hoje encontra-se a loja Capoane.

\section{REFERÊNCIAS}

A PEDIDO. Commercial, Paranaguá, ano II, n. 69, 18 jun. 1887. Disponível em: $<$ http://memoria.bn.br/DocReader/DocReader.aspx?bib=814288\&pesq=Joaquim\%20Antoni o\%20de\%20Loyola>. Acesso em: 22 abr. 2017.

ALVES, Alessandro Cavassin. A Província do Paraná e sua Assembleia Legislativa (1853-1889): a força política das famílias tradicionais. Curitiba: Máquina de Escrever, 2015.

ANTONINA. Dezenove de Dezembro, Curitiba, ano XX, n. 1440, 21 set. 1873, p. 4. Disponível em: $<$ http://memoria.bn.br/DocReader/DocReader.aspx?bib=416398\&PagFis=1357\&Pesq=jos\%C 3\%A9\%20machado\%20da\%20silva\%20lima>. Acesso em: 29 abr. 2017.

ANTONIO Loyola (Quinco). O Dia, Curitiba, 18 nov. 1952. Disponível em: < $<$ http://memoria.bn.br/DocReader/DocReader.aspx?bib=092932\&pesq=Joaquim\%20Antoni o\%20de\%20Loyola>. Acesso em: 22 abr. 2017.

ANÚNCIOS. Dezenove de Dezembro, Curitiba, ano XXXI, n. 146, 21 jun. 1884, p. 4. Disponível em: $<$ http://memoria.bn.br/DocReader/DocReader.aspx?bib=416398\&PagFis=11729\&Pesq=jos\% C3\%A9\%20machado\%20da\%20silva\%20lima>. Acesso em: 29 abr. 2017.

BANCO do Paraná. A República, Curitiba, ano VII, n. 795, 26 out. 1892. Disponível em: $<$ http://memoria.bn.br/DocReader/DocReader.aspx?bib=215554\&pesq=Joaquim\%20Ant onio\%20de\%20Loyola>. Acesso em: 23 abr. 2017.

BOURDIEU, Pierre. A ilusão biográfica. In: FERREIRA, Marieta de Moraes; AMADO, Janaína. (Orgs.). Usos \& Abusos da História Oral. 2. ed. Rio de Janeiro: FGV, 1998.

. Razões Práticas: sobre a teoria da ação. Campinas: Papirus, 2008.

BOURDIEU, Pierre. A llusão Biográfica. In: FERREIRA, Marieta de Moraes: AMADO, Janaína. (Orgs.). Usos \& Abusos da História Oral. 2. ed. Rio de Janeiro: FGV, 1998.

CANDIDATOS a Deputação. Dezenove de Dezembro, Curitiba, ano X, n. 415, 12 set. 1863, p. 3. Disponível

em: $<$ http://memoria.bn.br/DocReader/DocReader.aspx?bib=416398\&PagFis=1357\&Pesq=jos\%C 3\%A9\%20machado\%20da\%20silva\%20lima>. Acesso em: 29 abr. 2017. 
CANÊDO, Letícia Bicalho. Caminhos da Memória: parentesco e poder. Revista Textos de História, Brasília, v.2, n. 3, p. 85-122, 1994.

CARNEIRO, David; VARGAS, Túlio. História biográfica da República no Paraná. Curitiba: LíteroTécnica, 1987.

COMISSÕES CENSITÁRIAS. Diário de S. Paulo, São Paulo, ano IX, n. 2420, 16 nov. 1873. Disponível em:

<http://memoria.bn.br/DocReader/DocReader.aspx?bib=709557\&pesq=Antonio\%20Moreir a\%20Lima>. Acesso em: 22 abr. 2017.

CLUB Republicano. A República, Curitiba, ano V, n. 31, 6 fev. 1890. Disponível em: $<$ http://memoria.bn.br/DocReader/DocReader.aspx?bib=215554\&pesq=Joaquim\%20Antoni \%20de\%20Loyola>. Acesso em: 23 abr. 2017.

DECRETO N. 28. A República, Curitiba, ano V, n. 22, 26 jan. 1890. Disponível em: $<$ http://memoria.bn.br/DocReader/DocReader.aspx?bib=215554\&pesq=Joaquim\%20Antoni o\%20de\%20Loyola>. Acesso em: 23 abr. 2017.

DISTRICTO policial de São João da Graciosa. Almanak da Província do Paraná, 1876. Disponível em: $<$ http://memoria.bn.br/DocReader/DocReader.aspx?bib=823627\&pesq=Joaquim\%20Antoni o\%20de\%20Loyola>. Acesso em: 22 abr. 2017.

DOCUMENTOS contam a vida da Biblioteca Pública. Diário do Paraná, Curitiba, 7 mar. 1972, p. 8. Disponível em: $<$ http://memoria.bn.br/DocReader/DocReader.aspx?bib=761672\&pesq=jos\%C3\%A9\%20mac hado\%20da\%20silva\%20lima>. Acesso em: 28 abr. 2017.

EDITAIS. A República, Curitiba, ano XVIII, n. 33, p.3, 9 fev. 1903. Disponível em: <http://memoria.bn.br/DocReader/DocReader.aspx?bib=215554\&PagFis=10085\&Pesq=Joaq uim\%20Antonio\%20de\%20Loyola>. Acesso em: 23 abr. 2017.

EDITAIS. Dezenove de Dezembro, Curitiba, ano XX, n. 1436, 10 set. 1873, p. 2 e 4. Disponível em: $<$ http://memoria.bn.br/DocReader/DocReader.aspx?bib=416398\&PagFis=1357\&Pesq=ios\%C 3\%A9\%20machado\%20da\%20silva\%20lima>. Acesso em: 29 abr. 2017.

EXTRATO do expediente da Presidência do dia 29 de janeiro. Dezenove de Dezembro, Curitiba, ano IX, n. 358, 25 fev. 1863, p.2. Disponível em: $<$ http://memoria.bn.br/DocReader/DocReader.aspx?bib=416398\&pesq=jos\%C3\%A9\%20mac hado\%20da\%20silva\%20lima>. Acesso em: 29 abr. 2017.

FALECIMENTO. Diário de S. Paulo, São Paulo, ano XIII, n. 3980, 30 mar. 1878. Disponível em: <http://memoria.bn.br/DocReader/DocReader.aspx?bib=709557\&pesq=Antonio\%20Moreir a\%20Lima>. Acesso em: 22 abr. 2017. 
FUGIU no dia 17. Correio Paulistano, São Paulo, ano XXI, n. 5259, 25 mar. 1874. Disponível em: $<$ http://memoria.bn.br/DocReader/DocReader.aspx?bib=090972_03\&pesq=Antonio\%20Mor eira\%20Lima>. Acesso em: 22 abr. 2017.

GOULART, Mônica H. H. S. A Dança das Cadeiras: análise do jogo político na Assembleia Legislativa do Paraná. São Paulo: Paco Editorial, 2014.

. Entre Famílias e Secretarias: análise do arranjo político-administrativo do Paraná (18891930). In: OLIVEIRA, Ricardo Costa de. (Org.). Estado, Classe Dominante e Parentesco no Paraná. Blumenau: Nova Letra, 2015.

GUARDA Nacional. O Ipiranga, São Paulo, ano 2, n. 18, 1868. Disponível em: $<$ http://memoria.bn.br/DocReader/DocReader.aspx?bib=375420\&PagFis=1256\&Pesq=Anton io\%20Moreira\%20Lima>. Acesso em: 22 abr. 2017.

HOSPEDES e viajantes. Diário da Tarde, Curitiba, 24 jun. 1910. Disponível em: <http://memoria.bn.br/DocReader/DocReader.aspx?bib=800074\&pesq=Joaquim\%20Antoni o\%20de\%20Loyola>. Acesso em: 22 abr. 2017.

INTENDÊNCIA Municipal de Antonina. A República, Curitiba, ano V, n. 34, 9 fev. 1890. Disponível em:

$<$ http://memoria.bn.br/DocReader/DocReader.aspx?bib=215554\&pesq=Joaquim\%20Antoni o\%20de\%20Loyola>. Acesso em: 23 abr. 2017.

LEIS PROVINCIAIS. Diário de S. Paulo, São Paulo, ano VII, n. 2005, 22 jun. 1872. Disponível em: $<$ http://memoria.bn.br/DocReader/DocReader.aspx?bib=709557\&pesq=Antonio\%20Moreir a\%20Lima>. Acesso em: 22 abr. 2017.

LEME, Luiz Gonzaga da Silva. Genealogia Paulistana. vol. 5 e 6 . Disponível em: <http://www.arvore.net.br/Paulistana/Adenda 3.htm>. Acesso em: 19 abr. 2017.

LICENÇAS. Gazeta Paranaense, Curitiba, p. 2, 20 jul. 1887. Disponível em: <http://memoria.bn.br/DocReader/DocReader.aspx?bib=242896\&pesq=Joaquim\%20Antoni o\%20de\%20Loyola>. Acesso em: 22 abr. 2017.

LIGA Patriótica dos Paranaenses. Dezenove de Dezembro, Curitiba, ano XXVII, n. 183, 11 dez. 1889. Disponível <http://memoria.bn.br/DocReader/DocReader.aspx?bib=416398\&pesq=Joaquim\%20Antoni o\%20de\%20Loyola>. Acesso em: 23 abr. 2017.

LIMA, Antonio Jorge de Machado. CPDOC. Disponível em: $<$ http://www.fgv.br/cpdoc/acervo/dicionarios/verbete-biografico/lima-antonio-jorgemachado>. Acesso em: 28 abr. 2017. 
LOJA

ACÁCIA.

Museu

Maçônico.

Disponível

em: $<$ http://www.museumaconicoparanaense.com/MMPRaiz/LojaPRate1973/0715 obreiros.ht m>. Acesso em: 23 abr. 2017.

MACHADO,

Vicente.

CPDOC.

Disponível

em:

$<$ http://cpdoc.fgv.br/sites/default/files/verbetes/primeirarepublica/MACHADO,\%20Vicente.pdf>. Acesso em: 28 abr. 2017.

MANEJOS da Tribuna. Dezenove de Dezembro, Curitiba, ano XXXVII, n. 85, 9 ago. 1889, p. 3. Disponível

em:

$<$ http://memoria.bn.br/DocReader/DocReader.aspx?bib=416398\&PagFis=16105\&Pesq=vice nte\%20machado>. Acesso em: 29 abr. 2017.

MAQUIAVEL, Nicolau. O Príncipe. São Paulo: Cultrix, 1995.

MILAN, Poliana. Os ossos do Barão. Gazeta do Povo, Curitiba, 27 ago. 2010. Disponível em: $<$ http://www.gazetadopovo.com.br/conta/cadastrese/?referrer=http://www.gazetadopovo.com.br/vida-e-cidadania/os-ossos-do-barao2jl4s434yixvu0xwh28jgko5q>. Acesso em: 29 abr. 2017

MONTAGNER, Miguel Ângelo. Trajetórias e Biografias: notas para uma análise bourdieusiana. Revista Sociologias, Porto Alegre, n. 17, p. 240-265, jan./jun., 2007.

MONTEIRO, José Marciano. A Política como Negócio de Família: para uma sociologia política das elites e do poder político-familiar. São Paulo: LiberArs, 2017.

NEGRÃO, Francisco. Genealogia Paranaense. 6 vol. Curitiba: Imprensa Oficial do Estado do Paraná, 1926.

NIESS, Alexandre. Carreiras Políticas e Nepotismo na Terceira República Francesa (1871-1940). Revista Brasileira de Ciência Política, Brasília, n. 8, p. 71-100, maio/ago. 2012.

NíCOLAS, Maria. 130 Anos de Vida Parlamentar Paranaense 1854-1984. Curitiba: Setor de Editoração e Publicações da Coordenadoria de Estudos e Promoções Especiais, 1984.

NOTAS OFICIAIS. A República, Curitiba, ano XXV, n. 74, p.2, 1ㅇ abr. 1910. Disponível em: $<$ http://memoria.bn.br/DocReader/DocReader.aspx?bib=215554\&PagFis=10085\&Pesq=Joaq uim\%20Antonio\%20de\%20Loyola>. Acesso em: 23 abr. 2017.

NOTÍCIAS Diversas. Dezenove de Dezembro, Curitiba, 12 jan. 1861, ano VIII, n. 289, p. 3. Disponível em:

<http://memoria.bn.br/DocReader/DocReader.aspx?bib=416398\&pesq=jos\%C3\%A9\%20mac hado\%20da\%20silva\%20lima>. Acesso em: 29 abr. 2017.

NOTÍCIAS Diversas. Dezenove de Dezembro, Curitiba, 13 abr. 1861, ano VIII, n. 315, p.2. Disponível em: 
<http://memoria.bn.br/DocReader/DocReader.aspx?bib=416398\&pesq=jos\%C3\%A9\%20mac hado\%20da\%20silva\%20lima>. Acesso em: 29 abr. 2017.

O TESTAMENTO. Diário da Tarde, Curitiba, ano X, n. 2446, p. 2, 9 mar. 1907. Disponível em: <http://memoria.bn.br/DocReader/DocReader.aspx?bib=800074\&PagFis=9092\&Pesq=jos\%C 3\%A9\%20machado\%20da\%20silva\%20lima>. Acesso em: 29 abr. 2017.

OLIVEIRA, Marcus Roberto de. A regulamentação dos serviços de água e esgoto no século XIX: uma abordagem sobre o desempenho institucional da Câmara Municipal de Curitiba (1871-1900). Trabalho apresentado na Conferência Memória Política de Curitiba realizada em out. 2016 GT: Atividades Legislativas, Câmara Municipal de Curitiba, 2016.

OLIVEIRA, Ricardo Costa de. Na Teia do Nepotismo: sociologia política das relações de parentesco e poder político no Paraná e no Brasil. Curitiba: Editora Insight, 2012.

. O Silêncio dos Vencedores: genealogia, classe dominante e Estado no Paraná. Curitiba: Moinho do Verbo, 2001.

PAGAMENTO. Jornal do Commercio, Curitiba, ano II, n. 74, 1 nov. 1884. Disponível em: $<$ http://memoria.bn.br/DocReader/DocReader.aspx?bib=814415\&pesq=Joaquim\%20Antoni o\%20de\%20Loyola>. Acesso em: 22 abr. 2017.

PARTE OFICIAL. Dezenove de Dezembro, Curitiba, ano IV, n. 48, 10 out. 1857. Disponível em: $<$ http://memoria.bn.br/DocReader/DocReader.aspx?bib=416398\&pesq=jos\%C3\%A9\%20mac hado\%20da\%20silva\%20lima>. Acesso em: 29 abr. 2017.

PARTE OFICIAL. Dezenove de Dezembro, Curitiba, ano VII, n. 214, 21 abr. 1860. Disponível em: <http://memoria.bn.br/DocReader/DocReader.aspx?bib=416398\&pesq=jos\%C3\%A9\%20mac hado\%20da\%20silva\%20lima>. Acesso em: 29 abr. 2017.

PARTIDO Republicano. A República, Curitiba, ano IV, n. 54, 4 dez. 1889. Disponível em: $<$ http://memoria.bn.br/DocReader/DocReader.aspx?bib=215554\&pesq=Joaquim\%20Antoni o\%20de\%20Loyola>. Acesso em: 23 abr. 2017.

POMBO, R. Para a História: notas sobre a invasão federalista no Estado do Paraná. Curitiba; Fundação Cultural de Curitiba, 1980

PRIMEIRA. Gazeta Paranaense, Curitiba, p. 2, 15 abr. 1887. Disponível em: $<$ http://memoria.bn.br/DocReader/DocReader.aspx?bib=242896\&pesq=Joaquim\%20Antoni o\%20de\%20Loyola>. Acesso em: 22 abr. 2017.

SÊGA, Rafael Augustus. Tempos Belicosos: a Revolução Federalista no Paraná e a rearticulação da vida político-administrativa do estado (1889-1907). Curitiba: Aos Quatro Ventos; editora CEFET, 2005. 
VANALI, Ana Crhistina. "Ao Povo Paranaense": a vida do cidadão Manoel Corria Defreitas. 857 f. Tese (Doutorado em Sociologia), Universidade federal do Paraná, 2017.

VÁRIAS NOTÍCIAS. A República, Curitiba, ano XXIII, n. 293, p.2, 15 dez. 1908. Disponível em: <http://memoria.bn.br/DocReader/DocReader.aspx?bib=215554\&PagFis=10085\&Pesq=Joaq uim\%20Antonio\%20de\%20Loyola>. Acesso em: 23 abr. 2017.

VEREADORES. Almanak da Província do Paraná, 1876. Disponível em: <http://memoria.bn.br/DocReader/DocReader.aspx?bib=823627\&pesq=Joaquim\%20Antoni o\%20de\%20Loyola>. Acesso em: 22 abr. 2017.

Demais fontes jornalísticas - acervo consultado in loco, no Museu Paranaense:

Jornal Diário do Paraná, em 31 de julho de 1890.

Jornal O Dia, em 27 de março de 1907.

Jornal O Dia, em 27 de março de 1924.

Jornal O Dia, 27 de março de 1927.

Jornal Gazeta do Povo, 1924.

Jornal A República, em 31 de julho de 1897. 